\title{
An Empirical Study on the Shadow Price of Carbon Dioxide Emissions in China's Industry
}

\author{
Qunli Wu, Hongjie Zhang*, Ruke Zhang, Chunxiang Li \\ Department of Economics and Management, North China Electric Power University, Baoding, China
}

Received: 6 October 2018

Accepted: 8 May 2019

\begin{abstract}
The shadow price of $\mathrm{CO}_{2}$ emissions plays a fundamental role in evaluating $\mathrm{CO}_{2}$ abatement costs. In this paper, a directional environment production frontier function model based on the nonparametric method is established to measure the distance between actual production points and the effective production frontier surface, with which $\mathrm{CO}_{2}$ shadow prices of 36 industrial sectors in China are estimated during 2006-2015. The empirical studies show that: (1) there is a negative relationship between shadow price and carbon intensity. The average shadow price of the top five sectors with the highest carbon intensity is 373.92 Yuan/t, while the top five sectors with the lowest carbon intensity are 50254.54 Yuan/t. $\mathrm{CO}_{2}$ abatement potential differs significantly across sectors, so the sector-specific environmental policies should be concerned; (2) shadow prices of $\mathrm{CO}_{2}$ have an upward tendency with time in all sectors, and they rise with a greater speed in the low carbon intensity sectors than in the high ones, which implies that emissions reduction is accompanied by increasing economic sacrifices; (3) there is an additional $3.07 \%$ growth of industrial value owing to the $\mathrm{CO}_{2}$ emissions increasing by $6.39 \%$ every year; and (4) two typical sectors are selected to further analyze their $\mathrm{CO}_{2}$ abatement characteristics, respectively.
\end{abstract}

Keywords: shadow price, carbon dioxide emissions, industrial sectors, directional environment production frontier function

\section{Introduction}

The Paris Conference holds great significance in terms of establishing a legally binding and global agreement on climate change with the aim of keeping global warming below $2^{\circ} \mathrm{C}$ above preindustrial levels [1]. However, as one of the largest economies in the world, China is the biggest emitter worthy of the name

*e-mail: ncepuhjzhang@163.com and its annual growth of emissions has been more than the sum of North America and Europe [2]. As a responsible country, China has committed to reducing $\mathrm{CO}_{2}$ emissions per unit of GDP (i.e., carbon intensity) by $40-45 \%$ by 2020 compared to 2005 [3]. Furthermore, in the Paris Climate Conference, China's government pledged to peak its $\mathrm{CO}_{2}$ emissions no later than 2030 [4] and further reduce carbon intensity by $60-65 \%$ of the 2005 level $[5,6]$. Determining how large the economic sacrifice will be for achieving the upper goals has attracted increasing attention in recent literature [7, 
8]. The estimation of marginal abatement cost (MAC) is thus of great significance. In earlier studies, due to the lack of applicable tools, the cost of pollutants is generally measured with the physical quantity or the treatment cost of pollutants, which cannot reflect its real cost. Afterward, people gradually turned to simulate the shadow price of pollutants, which is the opportunity cost in terms of less output or more inputs when reducing the pollutant with one unit [9-11]. In recent years, the distance function has been widely used to estimate the shadow price of pollutants. It was first proposed by Shephard [12]. Afterward, Färe et al. [13] incorporated undesirable outputs into the Shephard distance function and constructed a Shephard output distance frontier function to estimate the shadow price of undesirable outputs. Hailu and Veeman [14] employed a translog Shephard input distance function to compute the shadow price. In this context, the Shephard distance function was creatively employed to derive the shadow price of pollutants and then there emerged massive literature for estimating the shadow price of pollutants based on it [15-20].

However, the Shephard distance function has the drawback of assuming the same proportional adjustment for all outputs (desirable and undesirable), which is not in accordance with the expectations of policymakers [21]. Comparatively, a directional distance function is able to distinguish the discrepancy between good outputs and bad ones with negative externality, and allows for the simultaneous expansion and contraction in desirable and undesirable outputs, respectively. Therefore, it can construct a model covering joint productions of good and bad outputs more objectively. So, in the presence of environmental regulation, the directional distance function is more suitable for estimating the shadow price of pollutants $[22,23]$. Matsushita and Yamane [24] employed a directional distance function to derive shadow prices of $\mathrm{CO}_{2}$ in the electric power sector of Japan. Xie et al. [25] investigated the inefficiency level, shadow price and substitution elasticity of industrial $\mathrm{SO}_{2}$ emissions in China from 1998 to 2011 based on a directional distance function. Lee et al. [26] conducted an empirical study with a directional distance function on Korea's electric power industry during the period of 1990-1995.

Generally, there are still two ways to describe a distance function, i.e., parametric or non-parametric [27]. Zeng et al. [28] used parametric directional distance function to estimate the shadow prices of China's provincial $\mathrm{SO}_{2}$ emissions for 2001-2013. Molinos-Senante et al. [29] employed a parametric model to estimate the shadow price of $\mathrm{CO}_{2}$ in 25 Spanish wastewater treatment plants in 2010. Molinos-Senante and Guzman [30] computed the shadow price of $\mathrm{CO}_{2}$ for the case of Chilean drinking water treatment plants using parametric directional distance function estimation. Generally speaking, the parametric method has specific economic meaning, while some defects still exist in this method. First, it needs to presuppose the function form of the production frontier, which is a great challenge for empirical research. Second, the parametric model confines the shadow price as an average result and the value of each individual cannot be obtained. Compared with the parametric method, the non-parametric method avoids the possible mistakes of falsely assuming the function form, and then becomes more flexible for the application. Second, it is insensitive to the measurement units of variables

Table 1. Summary of studies on estimating $\mathrm{CO}_{2}$ shadow prices of China's industrial sectors.

\begin{tabular}{|c|c|c|c|c|c|}
\hline Study & Sample & Period & Methodology & Shadow price & Unit \\
\hline Xie et al. [34] & 9 key industrial sectors & $2005-2014$ & P/NP-DDF & 731.75 & Yuan/t \\
\hline Du et al. [35] & 648 coal-fuelled power plants & 2008 & P-DDF & 235 & $\$ / t$ \\
\hline Du and Mao [36] & $518 / 640$ power plants & $2004 / 2008$ & P-DDF & $955 / 1142$ & Yuan/t \\
\hline Liu et al. [37] & Electric power generation sector & $2000-2012$ & P-DDF & 116.7 & Yuan/t \\
\hline Peng et al. [38] & Thermal power sector & $2004-2013$ & P-DDF & 316.21 & Yuan/t \\
\hline Xian et al. [39] & Power sector & $2011-2015$ & P-DDF & 294.5 & Yuan/t \\
\hline Liu and Lin [8] & Construction sector & $2003-2012$ & P-DDF & 567.1 & Yuan/t \\
\hline Wang et al. [40] & Construction sector & $2004-2014$ & P-DDF & 1698.04 & Yuan/t \\
\hline Lee and Zhang [41] & 30 manufacturing sectors & 2009 & P-SIDF & 3.13 & $\$ / t$ \\
\hline Yuan et al. [42] & 24 sectors & $2004 / 2008$ & NP-DDF & $15537 / 17258$ & Yuan/t \\
\hline Chen [43] & 38 industrial sectors & $1980-2008$ & P/NP-DDF & $26800 / 32700$ & Yuan/t \\
\hline Wang et al. [52] & Iron and steel sector & 2014 & P-DDF & 2563.67 & Yuan/t \\
\hline Wang and He [53] & Regional transportation sectors & $2007-2012$ & NP-DDF & 5410 & Yuan/t \\
\hline
\end{tabular}

Notes: SODF, SIDF and DDF denote Shephard output distance function, Shephard input distance function and directional distance function. P and NP denote parametric method and non-parametric method respectively. 
and need not transform the data into dimensionless form. Finally, the weights of inputs and outputs are decided through optimization solution, which improves the objectivity standard of the estimation. Although the non-parametric method ignores the impact of random shocks on the frontier output and its results cannot be statistically tested, the random impact is averaged and greatly weakened when the samples are most abundant, and it distorts little on the overall characteristics of the examined objects. Mekaroonreung and Johnson [31], Lee and Zhou [32], Kaneko et al. [33] and Xie et al. [34] all used the non-parametric method to describe the distance function and thereby estimate shadow prices of pollutants. Therefore, the non-parametric method is more practical for calculating the $\mathrm{CO}_{2}$ shadow price and is used in this study.

In China, industrial value-added accounted for over $30 \%$ of GDP, while its $\mathrm{CO}_{2}$ emissions account approximately for $88 \%$ of total emissions. More and more strict regulations on $\mathrm{CO}_{2}$ emissions undoubtedly hamper industrial production. So, $\mathrm{CO}_{2}$ shadow price in industry is well worth studying. Table 1 lists some previous studies on the $\mathrm{CO}_{2}$ shadow price of industrial sectors. Most of them focus on the $\mathrm{CO}_{2}$ shadow price in a single sector, such as power plants [35-39] or construction sector $[8,40]$. Some others focus on several sectors [41, 42]. Only a very few studies have covered all industrial sectors [43]. Therefore, shadow prices of $\mathrm{CO}_{2}$ emissions in all industrial sectors deserve further study.

There are four attributions of this paper: (1) construct a directional environment production frontier function model based on the non-parametric method, with which the $\mathrm{CO}_{2}$ shadow prices of 36 industrial sectors of China are estimated from 2006 to 2015; (2) divide all the industrial sectors into two groups of high-carbon and low-carbon intensity sectors. Then make a deep study of the characteristics and variation trends of $\mathrm{CO}_{2}$ shadow prices in each group, thereby putting forward sector-specific environmental policies and targets; (3) study the marginal effect and absolute effect of $\mathrm{CO}_{2}$ emissions on the industrial value-added and investigate the environmental cost of economic growth; (4) select the typical sector of Manufacture of Computers, Communication and other Electronic Equipment from the low-carbon intensity group and the sector of Production and Supply of Electric Power and Heat Power from the high-carbon intensity group respectively, for further analyzing their $\mathrm{CO}_{2}$ shadow prices and abatement potential.

The remainder of this paper is organized as follows. Section 2 constructs the directional environment production frontier function model that is applied to estimate the shadow price. Section 3 discusses data sources and statistical characteristics of variables. Section 4 denotes empirical results and discussions, and Section 5 denotes the main conclusions and policy implications.

\section{Methodology}

\section{Output Possibility Boundary}

In this paper, bad outputs are integrated into multioutput productivity measurement framework and then output possibility boundary is constructed [44].

$$
P(x)=\{(y, b): x \text { can produce }(y, b)\}
$$

$P(x)$ includes all optimal combinations of good outputs $(y)$ and bad outputs $(b)$. Here, inputs are expressed as $x_{k}(k=1, \ldots, K)$, while $y_{k}(u=1, \ldots, U)$ and $b_{v}(v=1, \ldots, V)$ respectively represent good outputs and bad outputs. There are four following assumptions about output possibility boundary $P(x)$.

(1) Free disposability or strong disposability of inputs means that good outputs would not be reduced as inputs increase, i.e., if $x_{1} \leq x_{2}$, then $P\left(x_{1}\right) \subseteq P\left(x_{2}\right)$

(2) Free disposability of good outputs denotes that a reduction in good outputs can be achieved at no cost, i.e., if $(y, b) \in P(x)$ and $y_{1} \leq y$, then $\left(y_{1}, b\right) \in P(x)$.

(3) Weak disposability means the abatement of bad outputs would not be free and usually at the expense of the reduction in good outputs, namely, if $(y, b) \in P(x)$, and $0 \leq \alpha \leq 1$, then $(\alpha y, \alpha b) \in P(x)$.

(4) Null-jointness indicates that good outputs and bad outputs belong to joint production, formally, if $(y, b)$ $\in P(x)$ and $b=0$ then $y=0$.

According to Färe et al. [13], a mathematical model is constructed to express output possibility boundary that satisfies the above hypotheses. Correspondingly, environmental technology is defined as:

$$
P(x)= \begin{cases}\lambda Y \geq y_{i, u}, & u=1, \ldots, U \\ \lambda X \leq x_{i, k}, & k=1, \ldots, K \\ \lambda B=b_{i, v}, & v=1, \ldots, V \\ \lambda_{i} \geq 0, & i=1, \ldots, I\end{cases}
$$

...where $i=1, \ldots, I$ represent decision-making units and $\left(X_{(I \times K)}, Y_{(I \times U)}, B_{(I \times V)}\right)$, represent input-output matrix. Meanwhile, $\lambda$ signifies the proportion that per unit of resource is used to put into production.

\section{Directional Environment Distance Function}

Directional environment distance function gives the possibility that good outputs increase while bad outputs decrease simultaneously. It fully describes the characteristics of the production process and inherits all properties of output possibility boundary. This paper assumes that good outputs and bad outputs satisfy the requirement for the above environmental technology and pollutant emissions have no constraint of environmental regulation.

According to Färe et al. [45], we specify the production technology by constructing directional 
environment output distance function with direction vector $\mathrm{g}=\left(g_{y},-g_{b}\right)$ and $g \neq 0$. Here, directional environment output distance function can be expressed as:

$$
\vec{D}_{0}\left(y, x, b ; g_{y},-g_{b}\right)=\sup \left[\delta:\left(y+\delta g_{y}, b-\delta g_{b}\right) \in P(x)\right]
$$

...where $\delta$ denotes the possible maximum reduction of bad outputs and expansion of good outputs under given production technology and inputs.

\section{Directional Environment Production Frontier Function}

\section{Static Directional Environment Production Frontier Function}

The relationship between directional environment production frontier function and directional environment distance function is:

$$
R\left(y, x, b ; g_{y}-g_{b}\right)=\left(1+\vec{D}_{0}\left(y, x, b ; g_{y},-g_{b}\right)\right) y
$$

This paper chooses $g=(y,-b)$ as the directional vector, which economically means the proportional expansion of good outputs and constriction of bad outputs is based on the existing scale. Fig. 1 gives the explanation of the directional environment production frontier function. According to whether or not to consider the period change, the function is divided into two types, namely static or dynamic directional environment production frontier function. In this sense, static directional environment production frontier function of $t$ period is constructed as follows:

$$
\begin{array}{lll}
R^{t}\left(y_{i}^{t}, x_{i}^{t}, b_{i}^{t} ; y_{i}^{t},-b_{i}^{t}\right)=\max _{\lambda, \delta}(1+\delta) y_{i}^{t} \\
\text { s.t } & \lambda_{i}^{t} Y_{I \times U}^{t} \geq(1+\delta) y_{i, u}^{t}, & u=1, \cdots, U \\
& \lambda_{i}^{t} X_{I \times K}^{t} \leq x_{i, k}^{t}, & k=1, \cdots, K \\
& \lambda_{i}^{t} B_{I \times V}^{t}=(1-\delta) b_{i, v}^{t}, & v=1, \cdots, V \\
& \lambda_{i}^{t} \geq 0, & i=1, \cdots, I
\end{array}
$$

Similarly, constructing static directional environment production frontier function in $(t+1)$ period only needs to replace the superscript $t$ of Equation (5) with $(t+1)$.

\section{Dynamic Directional Environment Production Frontier Function}

Dynamic directional environment production frontier function takes the period factor into account, which is utilized to analyze the relationship between pollutant changes and outputs in different periods. Here, first we construct a dynamic environment production frontier function with outputs and inputs of $t$ period:

$$
\begin{array}{lll} 
& R^{t}\left(y_{i}^{t}, x_{i}^{t}, b_{i}^{t+1} ; y_{i}^{t},-b_{i}^{t}\right)=\max _{\lambda, \delta}(1+\delta) y_{i}^{t} \\
\text { s.t } & \lambda_{i}^{t} Y_{I \times U}^{t} \geq(1+\delta) y_{i, u}^{t}, & u=1, \ldots, U \\
& \lambda_{i}^{t} X_{I \times K}^{t} \leq x_{i, k}^{t}, & k=1, \ldots, K \\
& \lambda_{i}^{t} B_{I \times V}^{t}=b_{i, v}^{t+1}-\delta b_{i, v}^{t} & v=1, \ldots, V \\
& \lambda_{i}^{t} \geq 0, & i=1, \ldots, I
\end{array}
$$

Secondly, a dynamic environmental production frontier function based on outputs and inputs of $(t+1)$ period is constructed.

$$
\begin{array}{cll}
R^{t+1}\left(y_{i}^{t+1}, x_{i}^{t+1}, b_{i}^{t} ; y_{i}^{t+1},-b_{i}^{t+1}\right) & =\max _{\lambda, \delta}(1+\delta) y_{i}^{t+1} \\
\text { s.t } & \lambda_{i}^{t+1} Y_{I \times U}^{t+1} \geq(1+\delta) y_{i, u}^{t+1}, & u=1, \ldots, U \\
\lambda_{i}^{t+1} X_{I \times K}^{t+1} \leq x_{i, k}^{t+1}, & k=1, \ldots, K \\
\lambda_{i}^{t+1} B_{I \times V}^{t+1}=b_{i, v}^{t}-\delta b_{i, v}^{t+1} & v=1, \ldots, V \\
\lambda^{t+1} \geq 0 . & i=1, \ldots, I
\end{array}
$$

$X_{I \times K}^{t}$ and $Y_{I \times U}^{t}$ are input matrix and output matrix with all decision-making units of $t$ period. Correspondingly, $X_{I \times K}^{t+1}$ and $Y_{I \times U}^{t+1}$ are respectively the input matrix and output matrix of $(t+1)$ period.

\section{Estimation of Shadow Price of $\mathrm{CO}_{2}$ Emissions}

Following Caves et al. [9] and Färe et al. [46], this paper exploits the geometric mean of environmental production frontier functions in two periods. Constructing marginal output effect $(M E)$ with the relationship between environment production frontier function and pollutants emissions is as follows:

$M E=\left[\frac{R^{t}\left(y^{t}, x^{t}, b^{t+1} ; y^{t},-b^{t}\right)}{R^{t}\left(y^{t}, x^{t}, b^{t} ; y^{t},-b^{t}\right)} \times \frac{R^{t+1}\left(y^{t+1}, x^{t+1}, b^{t+1} ; y^{t+1},-b^{t+1}\right)}{R^{t+1}\left(y^{t+1}, x^{t+1}, b^{t} ; y^{t+1},-b^{t+1}\right)}\right]^{\frac{1}{2}}-1$

This paper takes $\mathrm{CO}_{2}$ as bad outputs. From the perspective of the relationship between $\mathrm{CO}_{2}$ emissions and outputs, the shadow price of $\mathrm{CO}_{2}$ emissions can be expressed as:

$$
C S P=\frac{y_{i, t-1} X M E_{i, t}}{C O_{2 i, t}-C O_{2 i, t-1}}
$$

\section{Data Source and Statistical Characteristics of Variables}

This paper takes China's 36 industrial sectors as basic research units, where industrial value-added represents desirable outputs and $\mathrm{CO}_{2}$ emissions represent undesirable outputs. Capital stock, employees and energy consumption make up the inputs. All data are collected from [47-49]. Statistical descriptions of variables are listed in Table 2.

(1) Capital stock. Generally, annual real capital stock is estimated by the perpetual inventory method. 


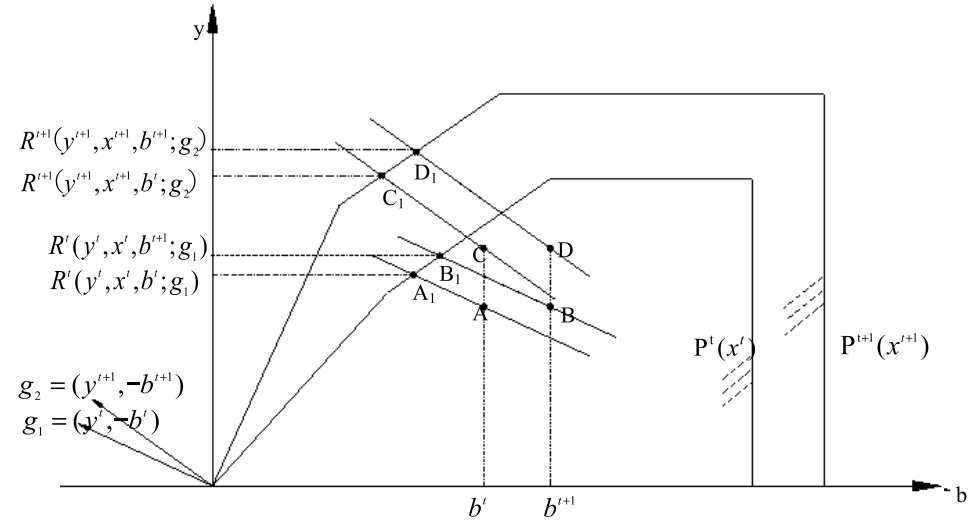

Fig.1. The illustration of Directional Environmental Production Frontier Function.

According to existing research results and the proposed method by Chen Shiyi [50], this paper extends current capital stock sequence to 2015 .

(2) Carbon dioxide emissions. Based on the method given by IPCC.2006 [51] and eight main energy sources (i.e. coal, coke, crude oil, gasoline, diesel oil, kerosene, natural gas and fuel oil), $\mathrm{CO}_{2}$ emissions can be estimated.

\section{Results and Discussion}

\section{Overall Analysis of the Industry}

\section{Sector Heterogeneity of the Shadow Price of $\mathrm{CO}_{2}$ Emissions}

In this section, 36 sectors are ranked in ascending order based on carbon intensity, and then the former half is defined as the low-carbon intensity sector (LCIS) while the latter half is the high-carbon intensity sector (HCIS). Then we analyze the characteristics of the shadow price and further discuss its sector heterogeneity.

Table 3 illustrates average shadow prices of $\mathrm{CO}_{2}$ emissions of 36 industrial sectors during 2005-2015. From it, we can see that the top five sectors with the highest carbon intensities are heavy chemical industrial sectors, whose average shadow price is 373.92 yuan/t far below the average value of the whole industry. On the contrary, the top five sectors with the lowest carbon intensity are equipment manufacturing sectors, in which the average shadow price is 50254.54 yuan/t - far above the average value of the whole industry. Thus it can be seen that shadow price has strong sector heterogeneity. The essence of emissions abatement lies in energy efficiency. On grounds of diverse $\mathrm{CO}_{2}$ emissions and energy efficiency across sectors, the difficulties and costs of further emissions abatement are quite different. Considering massive $\mathrm{CO}_{2}$ emissions and considerable room for improvement in energy efficiency in HCIS, it is relatively easy to reduce $\mathrm{CO}_{2}$ emissions, and as a result we do not need to pay much for it. On the contrary, LCIS possesses smaller emissions and higher energy efficiency, and further emissions abatement on this basis is more difficult and costly. Sequence the numbers in the second and fifth columns in ascending order and the order is indicated by the corresponding superscript. Then we can find that there is a negative relationship between carbon intensity and shadow price. As shown in Table 3, the sectors included in LCIS simultaneously embody the characteristics of low-carbon intensity and high shadow price, while the situation of sectors belonging to HCIS are completely opposite. For example, the carbon intensity of Manufacture of Computers,

Table 2. Statistical descriptions of variables.

\begin{tabular}{|c|c|c|c|c|c|}
\hline Variable & Number & Mean & Standard deviation & Minimum & Maximum \\
\hline Industrial value-added $\left(10^{8}\right.$ Yuan $)$ & 396 & 4332.89 & 4006.46 & 3.7 & 21217 \\
\hline Producer price index of industrial products $(2005=100)$ & 396 & 113.58 & 18.40 & 78.80 & 186.75 \\
\hline Capital stock $\left(10^{8}\right.$ Yuan) & 396 & 12283.90 & 15305.34 & 218.2 & 109125.36 \\
\hline Price index of investment on fixed assets $(2005=100)$ & 11 & 115.93 & 10.00 & 100 & 126.24 \\
\hline Annual average number of employees $\left(10^{4}\right.$ persons) & 396 & 341.71 & 278.55 & 0.3 & 1479.57 \\
\hline Energy consumption $\left(10^{4}\right.$ t of tce $)$ & 396 & 6499.75 & 11903.2 & 101.68 & 69342.42 \\
\hline $\mathrm{CO}_{2}$ emissions $\left(10^{4} \mathrm{t}\right)$ & 396 & 24112.25 & 63265.34 & 0.76 & 381628.06 \\
\hline
\end{tabular}

Note: tce refers to "standard" tons coal equivalent. 
Table 3. Shadow prices of $\mathrm{CO}_{2}$ emissions and output effects by sectors (averages during 2006-2015).

\begin{tabular}{|c|c|c|c|c|}
\hline Project & $\begin{array}{l}\text { Carbon intensity } \\
\left(\mathrm{t} / 10^{4} \text { Yuan }\right)\end{array}$ & $\begin{array}{l}\text { Marginal effect } \\
(\%)\end{array}$ & $\begin{array}{c}\text { Absolute effect } \\
\left(10^{8} \text { Yuan }\right)\end{array}$ & $\begin{array}{l}\text { Shadow price } \\
\text { (Yuan/t) }\end{array}$ \\
\hline \multicolumn{5}{|c|}{ Low Carbon Intensity Sector (LCIS) } \\
\hline Manufacture of Tobacco & $0.05^{1}$ & -1.57 & -71.10 & $40897.95^{34}$ \\
\hline $\begin{array}{l}\text { Manufacture of Computers, Communication } \\
\text { and other Electronic Equipment }\end{array}$ & $0.06^{2}$ & -0.18 & -88.70 & $83891.78^{36}$ \\
\hline Manufacture of Measuring Instrument and Machinery & $0.07^{3}$ & 0.77 & -6.26 & $62618.54^{35}$ \\
\hline Manufacture of Electrical Machinery and Apparatus & $0.14^{4}$ & 5.71 & 425.19 & $34179.63^{33}$ \\
\hline $\begin{array}{l}\text { Manufacture of Leather, Fur, Feather and Related Products } \\
\text { and Footwear }\end{array}$ & $0.15^{5}$ & 1.90 & 49.22 & $29684.80^{32}$ \\
\hline Manufacture of Furniture & $0.16^{6}$ & 4.13 & 34.36 & $29449.05^{31}$ \\
\hline Printing and Reproduction of Recording Media & $0.17^{7}$ & 4.06 & 44.16 & $28107.05^{30}$ \\
\hline Manufacture of Textile, Wearing Apparel and Accessories & $0.21^{8}$ & 0.83 & 14.99 & $21360.56^{28}$ \\
\hline $\begin{array}{l}\text { Articles for Culture, Education, Arts and Crafts, Sport and } \\
\text { Entertainment }\end{array}$ & $0.23^{9}$ & 7.83 & 71.72 & $23839.87^{29}$ \\
\hline Manufacture of Transportation Equipment & $0.27^{10}$ & 0.93 & -0.26 & $16727.58^{26}$ \\
\hline Production and Supply of Water & $0.28^{11}$ & 3.29 & 11.66 & $17583.98^{27}$ \\
\hline Manufacture of Metal Products & $0.33^{12}$ & 2.88 & 118.95 & $13991.53^{25}$ \\
\hline Manufacture of Special Purpose Machinery & $0.34^{13}$ & -0.43 & -74.88 & $13776.49^{23}$ \\
\hline Mining and Processing of Non-ferrous Metal Ores & $0.38^{14}$ & 3.65 & 40.50 & $12352.63^{22}$ \\
\hline Manufacture of General Purpose Machinery & $0.42^{15}$ & 2.41 & 58.69 & $10831.94^{21}$ \\
\hline Manufacture of Rubber and Plastic Products & $0.46^{16}$ & 1.95 & 64.34 & $9903.63^{20}$ \\
\hline Manufacture of Medicines & $0.51^{17}$ & 5.19 & 208.87 & $9251.71^{19}$ \\
\hline $\begin{array}{l}\text { Timber, Manufacture of Wood, Bamboo, Rattan, Palm and } \\
\text { Straw }\end{array}$ & $0.55^{18}$ & 22.14 & 195.97 & $13940.23^{24}$ \\
\hline Average & 0.27 & 3.64 & 60.97 & 26243.83 \\
\hline \multicolumn{5}{|c|}{ High Carbon Intensity Sector (HCIS) } \\
\hline Processing of Food from Agricultural Products & $0.65^{19}$ & 4.69 & 291.10 & $7346.11^{18}$ \\
\hline Manufacture of Liquor, Beverages and Refined Tea & $0.67^{20}$ & 3.53 & 115.54 & $7074.70^{17}$ \\
\hline Mining and Processing of Ferrous Metal Ores & $0.75^{21}$ & 5.33 & 61.01 & $5918.10^{16}$ \\
\hline Manufacture of Textile & $0.88^{22}$ & 4.48 & 358.12 & $5710.29^{15}$ \\
\hline Manufacture of Foods & $0.97^{23}$ & 3.62 & 89.68 & $4758.18^{14}$ \\
\hline Extraction of Petroleum and Natural Gas & $1.21^{24}$ & -0.49 & -33.30 & $4044.59^{13}$ \\
\hline Mining of Other Ores & $1.69^{25}$ & -9.28 & -0.06 & $2575.20^{11}$ \\
\hline Mining and Processing of Non-metal Ores & $1.86^{26}$ & 1.90 & 16.65 & $2417.16^{10}$ \\
\hline Manufacture of Chemical Fibers & $1.90^{27}$ & 1.42 & 19.92 & $2591.47^{12}$ \\
\hline Smelting and Pressing of Non-ferrous Metals & $3.21^{28}$ & 8.84 & 402.47 & $1654.08^{9}$ \\
\hline Manufacture of Paper and Paper Products & $3.45^{29}$ & 2.23 & 40.72 & $1345.90^{8}$ \\
\hline $\begin{array}{l}\text { Manufacture of Raw Chemical Materials and Chemical } \\
\text { Products }\end{array}$ & $5.72^{30}$ & 4.33 & 452.85 & $822.86^{7}$ \\
\hline Production and Supply of Gas & $6.95^{31}$ & -4.03 & -19.08 & $733.67^{6}$ \\
\hline Manufacture of Non-metallic Mineral Products & $7.00^{32}$ & 3.23 & 211.43 & $649.43^{5}$ \\
\hline Mining and Washing of Coal & $7.88^{33}$ & 4.17 & 200.75 & $608.39^{4}$ \\
\hline
\end{tabular}


Table 3. Continued.

\begin{tabular}{|c|c|c|c|c|}
\hline Smelting and Pressing of Ferrous Metals & $12.69^{34}$ & 3.22 & 299.72 & $371.55^{3}$ \\
\hline Production and Supply of Electric Power and Heat Power & $30.52^{35}$ & 2.32 & 177.20 & $157.59^{2}$ \\
\hline $\begin{array}{c}\text { Processing of Petroleum, Coking and Processing } \\
\text { of Nuclear Fuel }\end{array}$ & $59.96^{36}$ & 3.88 & 112.00 & $82.62^{1}$ \\
\hline Average & 8.22 & 2.41 & 155.37 & 2714.55 \\
\hline
\end{tabular}

Note: Superscripts in the second and fifth columns are the sequence numbers of each sector arranged with carbon intensity and shadow price in ascending order.

Communication and other Electronic Equipment is quite low at only $0.06 \mathrm{t} / 10^{4}$ yuan. However, its shadow price is the highest of 83891.78 yuan/t among sectors. Instead, processing of petroleum, coking and processing of nuclear fuel simultaneously possesses the highest carbon intensity of $59.96 \mathrm{t} / 10^{4}$ yuan and lowest shadow price of 82.62 yuan/t.

\section{Time Trend of the Shadow Price of $\mathrm{CO}_{2}$ Emissions}

Fig. 2 depicts the time trend of shadow price in the whole industry, with HCIS and LCIS during 20052015 separately. It shows that the average shadow prices of $\mathrm{CO}_{2}$ emissions in the whole industry has an obvious upward trend. With the exception of 2014, the shadow prices in other years are on the rise. To be specific, shadow prices increase from 7644.92 yuan/t in 2006 to 20765.58 yuan/t in 2015. The shadow prices in LCIS are at a high level, with an average of 26243.83 Yuan/t and increase over time. Conversely, the shadow prices of HCIS remain low with an average of 2714.55 Yuan/t, which are far below the average value of the whole industry and increase slowly. Based on this, the upward trend of the shadow price in the whole industry is mainly driven by LCIS, while HCIS has a finite contribution to it. An increase in the shadow price

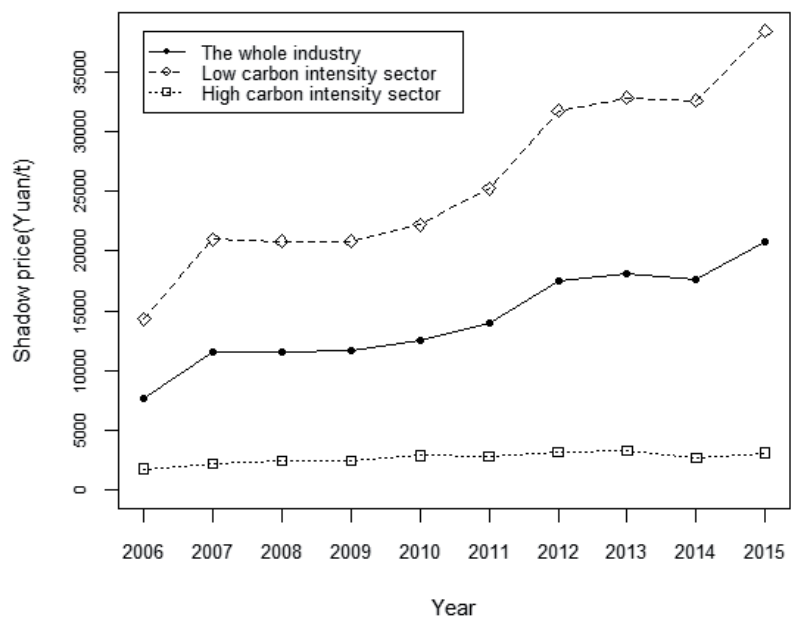

Fig. 2. Trends of average shadow price of $\mathrm{CO}_{2}$ emissions across sectors during 2006-2015. indicates that increasing a unit of $\mathrm{CO}_{2}$ can bring more industrial value-added and vice versa. On the one hand, shadow prices rise over time, which may be because it is calculated at a constant 2005 price in this paper, which implies a rising price trend. On the other hand, with the improvement of energy efficiency and the decline of carbon intensity, for a decision-making unit there is less space for emissions abatement. Consequently, further emissions abatement is costly as well as shadow price being on the rise similarly.

\section{Output Effects of $\mathrm{CO}_{2}$ Emissions}

Output effects of $\mathrm{CO}_{2}$ emissions can be observed in perspectives of marginal effect and absolute effect. Marginal effect is the index of output growth resulting from the increase or decrease of $\mathrm{CO}_{2}$ emissions with the given technical efficiency and inputs, and is expressed by the aforementioned $M E$. Absolute effect is used to measure the variation quantity of outputs caused by $\mathrm{CO}_{2}$ emissions change. Considering the weak disposability of Directional Environment Production Frontier Function, some costs have to be paid for reducing $\mathrm{CO}_{2}$ emissions. Therefore, output effects are always the same change direction as $\mathrm{CO}_{2}$ emissions. Fig. 3 portrays the marginal effect and absolute effect of $\mathrm{CO}_{2}$ emissions on outputs. From it, we can see that $\mathrm{CO}_{2}$ emissions have increased from 5.84 billion tons to 10.85 billion tons during 2005-2015, with a cumulative increase of $85.79 \%$, while the cumulative marginal effect of additional $\mathrm{CO}_{2}$ emissions on industrial value-added is only $30.69 \%$, that is, the absolute effect is 3894.14 billion yuan. In order to study the environmental costs of economic growth more specifically, a virtual growth rate is proposed, which is equal to the actual growth rate minus $M E$ (i.e., marginal effect). Fig. 3 shows that the virtual growth rates for $2006-2016$ are $15.04 \%, 15.04 \%, 6.18 \%, 9.03 \%, 8.17 \%$, $12.53 \%, 5.74 \%,-0.68 \%, 11.92 \%$, and $9.13 \%$ respectively, with an average of $9.21 \%$. Compared with the actual growth rates of $12.28 \%$, the difference is $M E$, whose value is $3.07 \%$. That is to say, for catching the annual $3.07 \%$ growth of industrial value-added, we must endure more $\mathrm{CO}_{2}$ emissions that are increased by $6.39 \%$ a year.

In this section, only the overall characteristics of $\mathrm{CO}_{2}$ shadow price and the environmental costs of economic growth in the whole industry can be seen while the specific situation of a sector cannot 


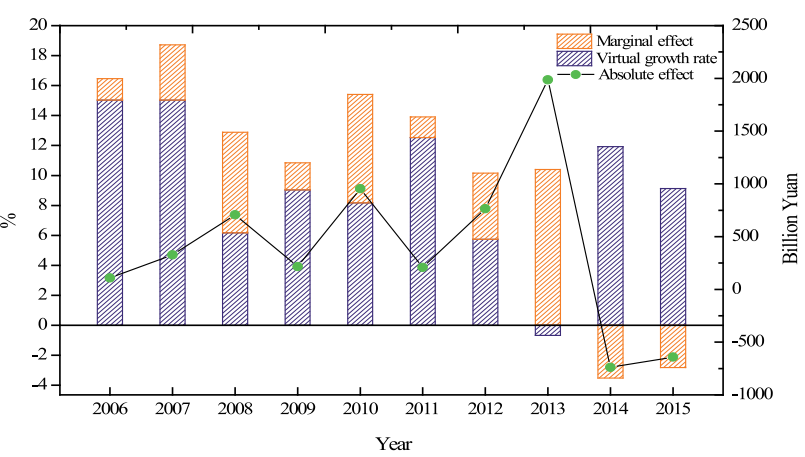

Fig. 3. Marginal effect and absolute effect of $\mathrm{CO}_{2}$ emissions on outputs.

be observed. Therefore, in the next section, we will explore the characteristics of $\mathrm{CO}_{2}$ shadow price and the environmental costs of economic growth in some specific sectors. On this basis, two representative sectors will be taken into account.

\section{Representative Cases Analysis}

\section{Low-Carbon Intensity Sector: Manufacture of Computers, Communications and Other Electronic Equipment}

Manufacture of computers, communication and other electronic equipment, a high-tech sector supported by China's government, is a kind of typical sector with low carbon intensity and high shadow price. Its overall carbon intensity is far below the whole industry, and decreasing with time, which indicates that its technical efficiency is at a high level and has an upward trend. Table 4 denotes that the $\mathrm{CO}_{2}$ emissions of this sector decreased from 6692.78 thousand tons in 2005 to
6030.25 thousand tons in 2015, i.e., $\mathrm{CO}_{2}$ emissions were reduced by $9.9 \%$. Due to emission abatement, industrial value-added is reduced by 88.7 billion yuan totally. Given that there are not only increases but also decreases in $\mathrm{CO}_{2}$ emissions during 2005-2015, the increase effect and reduction effect of $\mathrm{CO}_{2}$ emissions on outputs generally counteract each other. A simple addition of them would normally weaken the impact of $\mathrm{CO}_{2}$ emissions on outputs. Therefore, we separately calculate the contribution of increase and reduction in $\mathrm{CO}_{2}$ emissions to outputs. $\mathrm{CO}_{2}$ emissions increased by 3661.3 thousand tons in 2006-2008, 2012 and 2015. Accordingly, the industrial value-added is increased by 262.78 billion yuan, accounting for $4.23 \%$ of the total industrial value-added in the corresponding years. In other years, $\mathrm{CO}_{2}$ emissions are reduced by 4323.7 thousand tons, and the industrial valueadded consequently is reduced by 351.48 billion yuan, constituting $4.88 \%$ of the total industrial value-added in the corresponding years. From this perspective, the losses caused by emissions abatement are greater than the gains arising from an increase in $\mathrm{CO}_{2}$ emissions.

In this sector, virtual increase rates in this sector are $19.23 \%, 17.20 \%,-1.91 \%, 8.25 \%, 17.02 \%, 28.82 \%$, $2.70 \%, \quad 21.82 \%, \quad 12.62 \%, \quad 10.32 \%$ respectively, of which the mean is $13.61 \%$ rather than the actual $13.43 \%$. Industrial growth rate is decreased by $0.18 \%$ annually, which is the cost of emissions abatement in this sector.

As illustrated in Table 4, shadow prices of $\mathrm{CO}_{2}$ emissions in this sector increased significantly from 45055.22 yuan/t in 2006 to 159635.88 yuan/t in 2015 . Average shadow price is 83891.78 yuan/t, the highest level among all sectors, which denotes that energy efficiency is at a high level. In other words, increasing a unit of $\mathrm{CO}_{2}$ emissions would bring about more outputs

Table 4. Shadow prices and output effects of $\mathrm{CO}_{2}$ emissions in the manufacture of computers, communications and other electronic equipment (2005-2015).

\begin{tabular}{|c|c|c|c|c|c|c|c|c|}
\hline Item & $\begin{array}{c}\mathrm{CO}_{2} \\
\text { emissions } \\
\left(10^{4} \mathrm{t}\right)\end{array}$ & $\begin{array}{c}\mathrm{CO}_{2} \text { emissions } \\
\text { growth rate } \\
(\%)\end{array}$ & $\begin{array}{c}\text { Industrial } \\
\text { value-added } \\
\left(10^{8} \text { Yuan }\right)\end{array}$ & $\begin{array}{c}\text { Real industrial } \\
\text { growth } \\
(\%)\end{array}$ & $\begin{array}{c}\text { Carbon } \\
\text { intensity } \\
\left(\mathrm{t} / 10^{4} \text { Yuan }\right)\end{array}$ & $\begin{array}{c}\text { Marginal } \\
\text { effect } \\
(\%)\end{array}$ & $\begin{array}{c}\text { Absolute } \\
\text { effect } \\
\left(10^{8} \text { Yuan }\right)\end{array}$ & $\begin{array}{c}\text { Shadow } \\
\text { price } \\
(\text { Yuan/t) }\end{array}$ \\
\hline 2005 & 669.28 & 6057.02 & & 0.110 & & & \\
2006 & 680.92 & 1.74 & 7274.48 & 20.10 & 0.094 & 0.86 & 52.44 & 45055.22 \\
2007 & 692.16 & 1.65 & 8583.88 & 18.00 & 0.081 & 0.79 & 57.89 & 51497.32 \\
2008 & 898.05 & 29.75 & 9613.95 & 12.00 & 0.093 & 13.90 & 1193.66 & 57976.80 \\
2009 & 845.78 & -5.82 & 10123.49 & 5.30 & 0.084 & -2.95 & -283.97 & 54329.36 \\
2010 & 843.68 & -0.25 & 11834.36 & 16.90 & 0.071 & -0.13 & -12.57 & 59884.36 \\
2011 & 623.63 & -26.08 & 13716.02 & 15.90 & 0.045 & -12.92 & -1529.34 & 69501.00 \\
2012 & 758.81 & 21.68 & 15375.66 & 12.10 & 0.049 & 9.40 & 1289.19 & 95369.34 \\
2013 & 605.97 & -20.14 & 17113.11 & 11.30 & 0.035 & -10.52 & -1617.35 & 105821.78 \\
2014 & 600.85 & -0.84 & 19200.91 & 12.20 & 0.031 & -0.42 & -71.60 & 139846.76 \\
2015 & 603.03 & 0.36 & 21217.00 & 10.50 & 0.028 & 0.18 & 34.65 & 159635.88 \\
\hline
\end{tabular}


Table 5. Shadow prices and output effects of $\mathrm{CO}_{2}$ emissions in the production and supply of electric power and heat power (2005-2015).

\begin{tabular}{|c|c|c|c|c|c|c|c|c|}
\hline Item & $\begin{array}{c}\mathrm{CO}_{2} \\
\text { emissions } \\
\left(10^{4} \mathrm{t}\right)\end{array}$ & $\begin{array}{c}\mathrm{CO}_{2} \text { emissions } \\
\text { growth rate } \\
(\%)\end{array}$ & $\begin{array}{c}\text { Industrial } \\
\text { value-added } \\
\left(10^{8} \text { Yuan }\right)\end{array}$ & $\begin{array}{c}\text { Industrial } \\
\text { real growth } \\
(\%)\end{array}$ & $\begin{array}{c}\text { Carbon } \\
\text { intensity } \\
\left(\mathrm{t} / 10^{4} \text { Yuan }\right)\end{array}$ & $\begin{array}{c}\text { Marginal } \\
\text { effect } \\
(\%)\end{array}$ & $\begin{array}{c}\text { Absolute } \\
\text { effect } \\
\left(10^{8} \text { Yuan }\right)\end{array}$ & $\begin{array}{c}\text { Shadow } \\
\text { price } \\
(\text { Yuan/t })\end{array}$ \\
\hline 2005 & 214232.92 & 6173.84 & & 34.70 & & & \\
2006 & 243041.89 & 13.45 & 6988.79 & 13.20 & 34.78 & 6.51 & 402.02 & 139.55 \\
2007 & 265638.35 & 9.30 & 7953.24 & 13.80 & 33.40 & 4.55 & 317.66 & 140.58 \\
2008 & 274559.32 & 3.36 & 8637.22 & 8.60 & 31.79 & 1.67 & 132.44 & 148.46 \\
2009 & 291196.08 & 6.06 & 9155.45 & 6.00 & 31.81 & 2.99 & 257.84 & 154.98 \\
2010 & 304195.87 & 4.46 & 10162.55 & 11.00 & 29.93 & 2.21 & 202.13 & 155.49 \\
2011 & 343269.78 & 12.84 & 11188.97 & 10.10 & 30.68 & 6.23 & 632.94 & 161.99 \\
2012 & 350341.48 & 2.06 & 11748.42 & 5.00 & 29.82 & 1.02 & 114.66 & 162.14 \\
2013 & 381628.06 & 8.93 & 12476.82 & 6.20 & 30.59 & 4.37 & 513.35 & 164.08 \\
2014 & 354847.46 & -7.02 & 12751.31 & 2.20 & 27.83 & -3.57 & -445.72 & 166.43 \\
2015 & 335349.40 & -5.49 & 12815.07 & 0.50 & 26.17 & -2.79 & -355.28 & 182.21 \\
\hline
\end{tabular}

and vice versa. There exists high energy efficiency and less energy consumption, which means that further emissions abatement on the basis of its small scale of $\mathrm{CO}_{2}$ emissions is more difficult and costly.

\section{High Carbon Intensity Sector: Production and Supply of Electric Power and Heat Power}

The production and supply of electric power and heat power is a typical sector with high carbon intensity and low shadow price. It accounts for the largest proportion of the total $\mathrm{CO}_{2}$ emissions in the whole industry, approximately $35 \%$, while the industrial value-added constitutes only $6.42 \%$, between which there exists a significant discrepancy. Here, the serious mismatch between energy consumption and economic growth can be observed.

$4.58 \%$ annual average growth rate of $\mathrm{CO}_{2}$ emissions contributes to $7.66 \%$ expansion of outputs in this sector. Although there are not only increases but also decreases in carbon intensity, on the whole, it declines from $34.70 \mathrm{t} / 10^{4}$ yuan in 2005 to $26.17 \mathrm{t} / 10^{4}$ yuan in 2015 , which indicates that energy efficiency slightly improves during this period. This paper aims to know the effects of $\mathrm{CO}_{2}$ emissions on outputs when maintaining technical efficiency and inputs constant. $\mathrm{CO}_{2}$ emissions in this sector increased from 2142.33 million tons in 2005 to 3353.49 million tons in 2015, increasing by $56.53 \%$ during this period. Industrial value-added measured in constant 2005 price increases from 617.38 billion yuan in 2005 to 1281.51 billion yuan, increasing by approximately one-fold. Among them, the increase in $\mathrm{CO}_{2}$ emissions led to an increase of 177.2 billion yuan in outputs. However, $\mathrm{CO}_{2}$ emissions are decreased by 267.81 million tons and 194.98 million tons respectively in 2014 and 2015, in this sense, the increase effect and reduction effect of $\mathrm{CO}_{2}$ emissions on outputs would offset each other so that the actual effect of $\mathrm{CO}_{2}$ emissions on outputs cannot observed. Supposing that only the years with an increase in $\mathrm{CO}_{2}$ emissions are taken into account, the contribution of $\mathrm{CO}_{2}$ emissions to annual average industrial growth accounts for $2.32 \%$. When all years are considered, the virtual annual growth rate of this industry was $5.34 \%$ during 2006-2015, while the actual growth rate is $7.66 \%$. The extra $2.32 \%$ is at the environmental cost of $\mathrm{CO}_{2}$ increasing by $4.58 \%$ annually. Table 5 shows us that the shadow price of $\mathrm{CO}_{2}$ emissions has no obvious change over 2006-2015. For instance, shadow price was 139.55 Yuan/t in 2006, but in 2015 it is still only 182.21 yuan/t - far lower than the average shadow price in the whole industry. In view of this, an increase in outputs resulting from adding one unit of $\mathrm{CO}_{2}$ emissions is very limited. Similarly, reducing a unit of $\mathrm{CO}_{2}$ emissions is not costly. $\mathrm{CO}_{2}$ emissions in this sector are large, which constitute nearly $35 \%$ of the whole industry, while the shadow price is quite low. Therefore, emissions abatement is relatively easy. However, considering that the industry is closely related to basic people's livelihoods (although there exist low shadow price and high potential to reduce emissions), measures for reducing $\mathrm{CO}_{2}$ emissions have not yet been taken, as well as $\mathrm{CO}_{2}$ emissions have been increasing except for individual years.

\section{Conclusion and Policy Implications}

This paper employs a non-parametric model of the directional environment production frontier function model to estimate $\mathrm{CO}_{2}$ shadow price in 36 industrial sectors of China during 2006-2015, and achieves the main results of: 
(1) There is a negative relationship between $\mathrm{CO}_{2}$ shadow price and carbon intensity across sectors. The average shadow price of the top five sectors with the highest carbon intensity is 373.92 yuan/t, while that of the top five sectors with the lowest carbon intensities are 50254.54 yuan/t. $\mathrm{CO}_{2}$ abatement potential differs significantly across sectors, so the sectorspecific environmental policies or targets should be concerned.

(2) Shadow prices of $\mathrm{CO}_{2}$ emissions have an upward tendency with time in all sectors, and they rise with a greater speed in the low carbon intensity sectors than in the high ones, which implies that in China, economic sacrifices are increasing with carbon emissions reductions.

(3) $\mathrm{CO}_{2}$ emissions have increased from 5.84 billion tons to 10.85 billion tons during 2005-2015 in China's industrial sectors, with a cumulative increase of $85.79 \%$. While the cumulative marginal effect of $\mathrm{CO}_{2}$ emissions on industrial value-added is only $30.69 \%$, the absolute effect is 3894.14 billion yuan. With the technical efficiency and other inputs unchanged, there is an average $3.07 \%$ growth of industrial value-add of China owing to the increase in $\mathrm{CO}_{2}$ emissions every year, minus which the growth rate is only $9.21 \%$ rather than the official number of $12.28 \%$.

(4) The average shadow price of $\mathrm{CO}_{2}$ emissions in communication and other electronic equipment is 83891.78 yuan/t, which is the highest in all sectors. Additionally, its average actual and virtual growth rates of output are $13.43 \%$ and $13.61 \%$, respectively. Thus, energy efficiency is at a high level in this sector and further emissions abatement is more difficult and costly.

(5) $\mathrm{CO}_{2}$ emissions in the production and supply of electric power and heat power ranks No. 1 in all sectors while the shadow price is the lowest, which suggests there is a relatively huge potential in emissions abatement. Furthermore, an average 2.32\% growth of the value-added in this sector is owed to the growth of $\mathrm{CO}_{2}$ emissions by $4.58 \%$ annually. From the overall point of view, this sector should strengthen environmental regulations to control its emissions.

Our empirical results have several important implications. First, when government assigns the industrial sectors emission reduction targets, their sector heterogeneity pertaining to the shadow price should be considered. When the target exceeds their present ability, the sectors will pay a lot and be under considerable pressure. This paper finds that there is a negative relationship between shadow price and carbon intensity. That is, compared to the low carbon intensity sector, the high carbon intensity sector has the lower marginal abatement cost, thereby possessing a relatively huge potential for carbon emissions reduction. Hence, when the Chinese government places the burden of reducing carbon emissions on the industrial sectors, the high carbon intensity sectors should be assigned to more tasks while the low carbon intensity sectors are the opposite. Second, the Chinese government is constructing the emission trading scheme (ETS) and until now only the power generation sector is included in the national ETS. More sectors taking part in this scheme will undoubtedly improve market efficiency. Emission quotas flowing from sectors with low shadow price to the ones with high prices will have a win-win result, which can form a more instructive equilibrium price of emission quota and contribute to achieving the overall cost-effectiveness in reducing $\mathrm{CO}_{2}$ emissions. Third, with $\mathrm{CO}_{2}$ emissions, reducing the marginal abatement costs of sectors may increase with time. The government must take these changes into account when formulating emission reduction policies for preventing the emission reduction target assigned to the sectors beyond their ability to withstand. Fourth is that in recent years, many heavy industrial sectors of China encounter the problem of overcapacity. This study shows that the shadow prices of most heavy industrial sectors are relatively low, thereby having a large potential and space for emissions reduction. So, increasing the discharge standard of pollutants or eliminating enterprises that fail to meet the standard may be an effective way for urging these sectors to mitigate their carbon emissions. Finally, China's previous economic development model was extensive, which has brought severe environmental problems. It is predictable that with the price of carbon emission increasing, industrial sectors will have no choice but to apply cleaner energy or more effective production ways. So, with the reduction of carbon emissions, China will inevitably experience a deep revolution in the structures of economy and energy consumption.

\section{Author Contributions}

Qunli $\mathrm{Wu}$ designed this paper and made overall guidance, Hongjie Zhang wrote the manuscript, Ruke Zhang analyzed the data and Chunxiang Li contributed materials.

\section{Acknowledgements}

This study was supported by the National Social Science Fund (grant No. 17BGL252) and the Humanities and Social Sciences Planning Foundation of the Ministry of Education of China (grant No. 16YJA790052).

\section{Conflicts of Interest}

The authors declare no conflicts of interest. 


\section{References}

1. SCHURER A.P., MANN M.E., HAWKINS E., TETT S.F.B., HEGERL G.C. Importance of the preindustrial baseline for likelihood of exceeding Paris goals. Nature Climate Change. 7 (8), 563, 2017.

2. DONG F., YU B.L., HADACHIN T., DAI Y.J., WANG Y., ZHANG S.N., LONG R.Y. Drivers of carbon emission intensity change in China. Resour Conserv Recycl. 129, 187, 2018.

3. DONG F., LONG R.Y., YU B.L., WANG Y., LI J.Y., WANG Y., DAI Y.J., YANG Q.L., CHEN H. How can China allocate $\mathrm{CO}_{2}$ reduction targets at the provincial level considering both equity and efficiency? Evidence from its Copenhagen Accord pledge. Resour Conserv Recycl. 130, 31, 2018.

4. DONG F., WANG Y., SU B., HUA Y., ZHANG Y. The process of peak $\mathrm{CO}_{2}$ emissions in developed economies: A perspective of industrialization and urbanization. Resources, Conservation and Recycling. 141, 61, 2019.

5. DONG F., BIAN Z.F., YU B.L., WANG Y., ZHANG S.N., LI J.Y., SU B., LONG R.Y. Can land urbanization help to achieve $\mathrm{CO}_{2}$ intensity reduction target or hinder it? Evidence from China. Resour Conserv Recycl. 134, 206, 2018.

6. DONG F., DAI Y., ZHANG S., ZHANG X., LONG R. Can a carbon emission trading scheme generate the Porter effect? Evidence from pilot areas in China. Sci Total Environ. 653, 565, 2018.

7. YI B.W., XU J.H., FAN Y. Determining factors and diverse scenarios of $\mathrm{CO}_{2}$ emissions intensity reduction to achieve the $40-45 \%$ target by 2020 in China - a historical and prospective analysis for the period 2005-2020. Journal of Cleaner Production. 122, 87, 2016.

8. LIU H.X., LIN B.Q. Cost-based modelling of optimal emission quota allocation. Journal of Cleaner Production. 149, 472, 2017.

9. CAVES D.W., CHRISTENSEN L.R., DIEWERT W.E. The Economic Theory of Index Numbers and the Measurement of Input, Output, and Productivity. Econometrica. 50 (6), 1393, 1982.

10. PITTMAN R.W. Issues in pollution control: interplant cost differences and economics of scale. Land Econ. 57, 1, 1981.

11. PITTMAN R.W. Multilateral Productivity Comparisons with Undesirable Outputs. The Economic Journal. 93 (372), 883, 1983.

12. SHEPHARD R.W. Theory of cost and production functions. Princeton. Princeton University Press. 1970.

13. FARE R.G.S., LOVELL C.A., YAISAWARNG S. Derivation of shadow prices for undesirable outputs: a distance function approach. Rev Econ Stat. 75, 374, 1993.

14. HAILU A., VEEMAN T.S. Environmentally Sensitive Productivity Analysis of the Canadian Pulp and Paper Industry, 1959-1994: An Input Distance
Function Approach. Journal of Environmental Economics \& Management. 40 (3), 251, 2000.

15. HERNANDEZ-SANCHO F., MOLINOS-SENANTE M., SALA-GARRIDO R. Economic valuation of environmental benefits from wastewater treatment processes: An empirical approach for Spain. Science of the Total Environment. 408 (4), 953, 2010.

16. KWON O.S., YUN W.C. Estimation of the marginal abatement costs of airborne pollutants in Korea's power generation sector. Energy Economics. 21 (6), 547, 1999.

17. LEE M. The shadow price of substitutable sulfur in the US electric power plant: A distance function approach. Journal of Environmental Management. 77 (2), 104, 2005.

18. LEE M. Potential cost savings from internal/external $\mathrm{CO}_{2}$ emissions trading in the Korean electric power industry. Energy Policy. 39 (10), 6162, 2011.

19. COGGINS J.S., SWINTON J.R. The Price of Pollution: A Dual Approach to Valuing $\mathrm{SO}_{2}$ Allowances. Journal of Environmental Economics \& Management. 30 (1), 58, 1996.

20. MURTY M.N., KUMAR S., PAUL M. Environmental regulation, productive efficiency and cost of pollution abatement: a case study of the sugar industry in India. Journal of Environmental Management. 79 (1), 1, 2006.

21. ZHOU P., ZHOU X., FAN L.W. On estimating shadow prices of undesirable outputs with efficiency models: A literature review. Applied Energy. 130, 799, 2014.

22. WANG K., WEI Y.M., ZHANG X. Energy and emissions efficiency patterns of Chinese regions: A multi-directional efficiency analysis. Applied Energy. 104, 105, 2013.

23. WANG Q.W., ZHOU P., ZHOU D.Q. Efficiency measurement with carbon dioxide emissions: The case of China. Applied Energy. 90 (1), 161, 2012.

24. MATSUSHITA K., YAMANE F. Pollution from the electric power sector in Japan and efficient pollution reduction. Energy Economics. 34 (4), 1124, 2012.

25. XIE H.M., SHEN M.H., WEI C. Technical efficiency, shadow price and substitutability of Chinese industrial $\mathrm{SO}_{2}$ emissions: a parametric approach. Journal of Cleaner Production. 112, 1386, 2016.

26. LEE J.D., PARK J.B., KIM T.Y. Estimation of the shadow prices of pollutants with production/ environment inefficiency taken into account: a nonparametric directional distance function approach. Journal of Environmental Management. 64 (4), 365, 2002.

27. SIDHOUM A.A. Valuing social sustainability in agriculture: An approach based on social outputs' shadow price. Journal of Cleaner Production. 203, 273, 2018.

28. ZENG S.H., JIANG X., SU B., NAN X. China's $\mathrm{SO}_{2}$ shadow prices and environmental technical efficiency at the province level. International Review of Economics \& Finance. 57, 86, 2018. 
29. MOLINOS-SENANTE M., HANLEY N., SALAGARRIDO R. Measuring the $\mathrm{CO}_{2}$ shadow price for wastewater treatment: A directional distance function approach. Applied Energy. 144, 241, 2015.

30. MOLINOS-SENANTE M., GUZMÁN C. Reducing $\mathrm{CO}_{2}$ emissions from drinking water treatment plants: A shadow price approach. Applied Energy. 210, 623, 2018.

31. MEKAROONREUNG M., JOHNSON A.L. Estimating the shadow prices of $\mathrm{SO}_{2}$ and $\mathrm{NO}_{x}$ for U.S. coal power plants: A convex nonparametric least squares approach. Energy Economics. 34 (3), 723, 2012.

32. LEE C.Y., ZHOU P. Directional shadow price estimation of $\mathrm{CO}_{2}, \mathrm{SO}_{2}$ and $\mathrm{NO}_{\mathrm{x}}$ in the United States coal power industry 1990-2010. Energy Economics. 51, 493, 2015

33. KANEKO S., FUJII H., SAWAZU N., FUJIKURA R. Financial allocation strategy for the regional pollution abatement cost of reducing sulfur dioxide emissions in the thermal power sector in China. Energy Policy. 38 (5), 2131, 2010.

34. XIE B.C., DUAN N., WANG Y.S. Environmental efficiency and abatement cost of China's industrial sectors based on a three-stage data envelopment analysis. Journal of Cleaner Production. 153 (1), 626, 2017.

35. DU L.M., HANLEY A., ZHANG N. Environmental technical efficiency, technology gap and shadow price of coal-fuelled power plants in China: A parametric meta-frontier analysis. Resource and Energy Economics. 43, 14, 2016.

36. DU L.M., MAO J. Estimating the environmental efficiency and marginal $\mathrm{CO}_{2}$ abatement cost of coal-fired power plants in China. Energy Policy. 85, 347, 2015.

37. LIU L., SUN X., CHEN C., ZHAO E.D. How will auctioning impact on the carbon emission abatement cost of electric power generation sector in China? Applied Energy. 168, 594, 2016.

38. PENG J., YU B.Y., LIAO H., WEI Y.M. Marginal abatement costs of $\mathrm{CO}_{2}$ emissions in the thermal power sector: A regional empirical analysis from China. Journal of Cleaner Production. 171, 163, 2018.

39. XIAN Y., WANG K., WEI Y.M., HUANG Z. Would China's power industry benefit from nationwide carbon emission permit trading? An optimization model-based ex post analysis on abatement cost savings. Applied Energy. 235, 978, 2019.
40. WANG K., YANG K., WEI Y.M., ZHANG C. Shadow prices of direct and overall carbon emissions in China's construction industry: A parametric directional distance function-based sensitive estimation. Structural Change and Economic Dynamics. 47, 180-93, 2018.

41. LEE M., ZHANG N. Technical efficiency, shadow price of carbon dioxide emissions, and substitutability for energy in the Chinese manufacturing industries. Energy Economics. 34 (5), 1492, 2012.

42. YUAN P., LIANG W.B., CHENG S. The Margin Abatement Costs of $\mathrm{CO}_{2}$ in Chinese industrial sectors. $20112^{\text {nd }}$ International Conference on Advances in Energy Engineering. 1792, 2012.

43. CHEN S.Y. Shadow price of industrial carbon dioxide: Parametric and non Parametric method. World economy. 33 (8), 93, 2010.

44. FARE R., GROSSKOPF S., WEBER W.L. Shadow prices and pollution costs in US agriculture. Ecological Economics. 56 (1), 89, 2006.

45. FARE R., GROSSKOPF S., CARL A., PASURKA J.R. Accounting for Air Pollution Emissions in Measures of State Manufacturing Productivity Growth. Journal of Regional Science. 41 (3), 381, 2001.

46. FARE R., GROSSKOPF S., NORRIS M. Productivity Growth, Technical Progress, and Efficiency Change in Industrialized Countries: Reply. American Economic Review. 84 (5), 1040, 1994.

47. NBSC. China Statistical Yearbook. Beijing: China Statistics Press. 2005-2015.

48. NBSC. China Labour Statistical Yearbook. China Statistics Press. 2005-2015.

49. NBSC. China Energy Statistical Yearbook. Beijing: China Statistics Press. 2005-2015.

50. CHEN S.Y. Estimation of statistical data in China's sub-industrial sectors: 1980-2008. Economic Quarterly. 10 (3), 735, 2011.

51. IPCC. 2006 IPCC Guidelines for National Greenhouse Gas Inventories: Volume II Energy. Japan: Institute for Global Environmental Strategies. 2006.

52. WANG K., CHE L., MA C., WEI Y.M. The shadow price of $\mathrm{CO}_{2}$ emissions in China's iron and steel industry. Sci Total Environ. 598, 272, 2017.

53. WANG Z.H., HE W.J. $\mathrm{CO}_{2}$ emissions efficiency and marginal abatement costs of the regional transportation sectors in China. Transportation Research Part D-Transport and Environment. 50, 83, 2017. 